\title{
EFFECT OF ARBUSCULAR MYCORRHIZAL COLONIZATION ON EARLY GROWTH AND NUTRIENT CONTENT OF TWO PEAT- SWAMP FOREST TREE SPECIES SEEDLINGS, Calophyllum bosei AND Ploiarium alternifolium
}

\author{
Maman Turjaman ${ }^{1}$, Erdy Santoso ${ }^{1}$, Yutaka Tamai ${ }^{2}$, Mitsuru Osaki ${ }^{2}$, Keitaro Tawaraya $^{3}$
}

\begin{abstract}
Tropical peat-swamp forests are one of the largest near-surface reserves of terrestrial organic carbon, but many peat-swamp forest tree species decreased due over-exploitation, forest fire and conversion of natural forests into agricultural lands. Among those species are slow-growing Calophyllum bosei and Ploiarium alternifolium, two species are good for construction of boats, furniture, house building and considerable attention from pharmacological viewpoint for human healthly. This study was aimed at understanding the effects of arbuscular mycorrhizal (AM) fungi on early growth of $C$. bosei and $P$. alternifolium under greenhouse condition. Seedlings of $C$. hosei and $P$. alternifolium were inoculated with AM fungi: Glomus clarum and Glomus aggregatum, or uninoculated under greenhouse condition during 6 months. AM colonization, plant growth, survival rate and nutrient content $(\mathrm{P}, \mathrm{Zn}$ and $\mathrm{B})$ were measured. The percentage of C. bosei and P. alternifolium ranged from $27-32 \%$ and $18-19 \%$, respectively. Both inoculated seedling species had greater plant height, diameter, leaf number, shoot and root dry weight than control seedlings. Nutrient content of inoculated plants were increased with AM colonization. Survival rates of inoculated plants were higher $(100 \%)$ than those of control plants $(67 \%)$. The results suggested that inoculation of AM fungi could improve the early growth of C. hosei and $P$. alternifolium grown in tropical peat-swamp forest therefore this finding has greater potential impact if this innovative technology applied in field scales which are socially acceptable, commercially profitable and environmentally friendly.
\end{abstract}

Keywords: AM fungi, peat-swamp forest, Calophyllum bosei, Ploiarium alternifolium, rehabilitation

\section{INTRODUCTION}

Arbuscular mycorrbizal (AM) fungi are vital components of almost all terrestrial ecosystems, forming mutually beneficial symbiosis with the roots of approximately $80 \%$ of vascular plants and frequently increasing phosphate (P) uptake and growth (Smith et al., 2003). As well they increase uptake of nitrogen $(N)$ from the soil either directly or through improvements in the plant P supply (George, 2000). One suggested that up to $80 \%$ of the P and $25 \%$ of the $\mathrm{N}$ taken up by a mycorrhizal fungi can be supplied by the fungus (Marschner and Dell, 1994). AM fungi can also supply other micronutrient such as $\mathrm{Zn}$ and $\mathrm{Cu}$ (Smith and Read, 1997). Besides AM fungi can play an important role on the water relation and reduce the effects of drought stress of host plants (Augé et al., 2003). AM fungi activity in the soil can

\footnotetext{
${ }^{1}$ Forest Microbiology Laboratory, Forest and Nature Conservation Research and Development Center, Bogor, Indonesia

${ }^{2}$ Graduate School of Agriculture, Hokkaido University, Sapporo 060-8589, Japan

${ }^{3}$ Faculty of Agriculture, Yamagata University, Tsuruoka 997-8555, Japan
} 
lead to increase soil aggregation (Miller and Jastrow, 2000), which improves drainage, and soil quality in sustainable maintenance of plant health (Jeffries et al., 2003). In addition AM associations can reduce damage caused by soil-borne plant pathogens (Azcón-Aguilar and Barea, 1996). These associations are of great importance in forest ecology, succession, plant growth and land rehabilitation of deforested lands in the tropical rain forest (Guadarrama $e t$ al., 2004). However, information about the diversity and the role of this symbiosis in Southeast Asian rain forest is limited.

Indonesia tropical peat swamp forests have the largest area of peat in the tropical zone, and are located at low altitude in the coastal and sub coastal lowlands of Irian Jaya (4.6 Mha), Sumatra (8.3 Mha) and Kalimantan (6.8 Mha) (Page et al., 1999). The Dipterocarpaceae family is the dominant group of trees in Kalimantan, in abundance, density and biomass. The family of Dipterocarpaceae is considered frequently to be ectomycorrhizas (Lee, 1990). Slik et al. (2003) surveyed the 10 most abundant of tree families after Dipterocarpaceae were Euphorbiaceae, Myrtaceae, Sapotaceae, Lauraceae, Myristicaceae, Burseraceae, Anacardiaceae, Ebenaceae, Annonaceae and Guttiferae. These families are considered a dominance of arbuscular mycorrhizas (AM) (Tawaraya et al., 2003).

The majority problem hampering the growth of tree species in peat-swamp forest is associated with the early growths of forest seedlings; the growth is often very slow and later, become stagnant. Ploiarium seeds germinate unsatisfactorily when sown immediately after collection, but Ploiarium is favoured by cuttings (Sosef et al., 1998). Calophyllum seeds (Guttiferae) have a low germination capacity and seeds are often lost in floods during the rainy season, further limiting reproduction (Nair and Seeni, 2003). In addition, Gonystylus bancanus (Thymeleaceae) is commercials timbers from peat-swamp forest but this species have decreased sharply due to over exploitation and it is categorized as vulnerable in Appendix 2 CITES (CITES, 2005). Under natural condition, G. bancanus belongs to slow growing species and appears to have irregular flowering and fruiting habits, i.e. the month of flowering differs and it does not flower every year (Soerianegara and Lemmens, 1994).

Calophyllum and Ploaiarium are important species from Guttiferae family, and are widely studied by the scientific community (Khan et al., 2002; Leong and Harrison, 1999). Several species of Calophyllum and Ploaiarium were used in medicine, antimicrobial activity and other biological active compound research such as coumarins, xanthones, terpenoids. In recent times Calophyllum species have received considerable attention from pharmacological viewpoint, since some of them produce potent inhibitors of reverse transcriptase of HIV (human immunodeficiency virus) (Reyes-Chilpa et al., 1997). Some Calophyllum timbers are good for construction of boats and furniture and suitable for plywood, but Ploiarium is used for house building and firewood as well as charcoal for local people (Sosef et al.,1998).

Arbuscular mycorrbizas are the central role of microbial symbioses for the greater part of plants, under conditions of P-restriction, effect plant growth productivity, plant community development, water relations and nutrient uptake (Jeffries et al., 2003). Nevertheless, very little information is available on supposedly various benefits to plant growth, nutrient uptake and survival rates conferred by the AM fungi on Calophyllum and Ploaiarium species. The present study aimed at understanding the effects of AM fungi on early growth and nutrient uptake of Calophyllum hosei Ridley and Ploiarium alternifolium (Vahl) Melchior (synonym $=$ Hypericum alternifolium Vahl) (Kobuski, 1950), the slow-growing peat-swamp forest species of Indonesia, under greenhouse condition. 


\section{MATERIALS AND METHODS}

Ultisol was collected from Haurbentes Experimental Forest, Jasinga, West Java $\left(6^{\circ} 32^{\prime}-\right.$ $33^{\prime} \mathrm{S}, 108^{\circ} 26^{\prime} \mathrm{E}$ ) and stored in greenhouse. The soil was sieved to pass through $<5 \mathrm{~mm}$ and then mixed with river sand $(3: 1, \mathrm{v} / \mathrm{v})$ to improve drainage. The $\mathrm{pH}(\mathrm{H} 2 \mathrm{O})$ of mixed soil was 4.8 and available $\mathrm{P}$ (Bray-1) was $0.17 \mathrm{mg} \mathrm{kg}-1$. The mixed soil was sterilized at $121{ }^{\circ} \mathrm{C}$ for 30 minutes. Cutting materials of $C$. hosei and $P$. alternifolium were collected from wildlings at Nyaru Menteng arboretum near Palangkaraya in Central Kalimantan, Indonesia. The cuttings were cut to a length of about $10 \mathrm{~cm}$ with two leaves. The leaf area was reduced to about a half of its original size. Roots of two seedling species were stimulated by rooton (Ishihara Sangyo Co. ${ }^{\circledR}$, Japan). Crushed coconut fiber mixed with rice husks $(2: 1, v / v)$ were used for the cutting medium. The media was sterilized at $121{ }^{\circ} \mathrm{C}$ temperatures with $1 \mathrm{~atm}$ pressure for 50 minutes. Subsequently, the cuttings were placed in 45-hole pot-trays, one cutting was per hole. The periode growth of cuttings was 90 days. A fog evaporative cooling system was installed inside the greenhouse to lower temperature inside the propagator (Sakai et al., 2002). Inoculum of AM containing Glomus aggregatum Schenk \& Smith propagule was obtained from R\&D (Research and Development) Osaka Gas Company (Japan) and Glomus clarum Nicholson \& Schenk was isolated from peat soil of Kalampangan, Palangkaraya, Central Kalimantan by trap culture. G. clarum were propagated in pot cultures of Pueraria javanica. Plastic pots were filled with $175 \mathrm{~g}$ sterilized zeolite and $5 \mathrm{~g} \mathrm{AM}$ inoculum. The polyethylene pots (size $15 \times 10 \mathrm{~cm}$ ) were filled with $500 \mathrm{~g}$ sterilized mixed soil. AM inoculation was achieved by placing $5 \mathrm{~g}$ AM inoculum of each species $1-3 \mathrm{~cm}$ under seedling. One 90 -day-old C. hosei or $P$. alternifolium seedling was transplanted into pots. Seedlings were watered daily with tap water to a field capacity. Weed and pest controls were carried out manually. The seedlings were grown for 180 days in a greenhouse of Forest and Nature Conservation Research and Development Center (FNCRDC), Bogor, West Java.

The experiment consisted of three treatments for $C$. hosei and $P$. alternifolium seedlings (a) control; (b) G. aggregatum; (c) G. clarum. There were 15 replications of both species per treatment. Shoot height and stem diameter at $1 \mathrm{~cm}$ from surface of soil were measured 180 days after transplanting. Shoots were harvested and separated. Shoots and roots were ovendried at $70^{\circ} \mathrm{C}$ for $72 \mathrm{~h}$ before weighing. Ground shoots were digested by $\mathrm{H} 2 \mathrm{SO} 4$ and $\mathrm{H} 2 \mathrm{O} 2$ solution $(3: 1, \mathrm{v} / \mathrm{v})$. The phosphorus $(\mathrm{P})$ content in the digested solution were determined by the vanado molybdate yellow method. An additional 15 seedlings of both $C$. hosei and $P$. alternifolium inoculated with $G$. aggregatum, $G$. clarum or uninoculated were grown as same as the seedlings in the above experiment. Numbers of alive seedling were counted 180 days after transplanting. Survival rate was calculated as follows; Survival rate $(\%)=$ number of alive seedlings / number of initial seedlings $15 \times 100$. The roots of $C$. bosei and $P$. alternifolium were cleared in $100 \mathrm{~g} \mathrm{l}-1 \mathrm{KOH}$ for $1 \mathrm{~h}$, acidified with diluted $\mathrm{HCl}$ and stained with $500 \mathrm{mg} \mathrm{l}-1$ tryphan blue in lactoglycerol (Brundrett et al., 1996). The percentage root length colonized by AM fungi was estimated by scoring the presence or absence of AM fungal structures (McGonigle et al., 1990). Data were statistically analysed using analysis of variance (ANOVA) with the statistical software StatView 5.0 (Abacus Concepts). Comparison of means was done using the least significant difference (LSD) method at the $5 \%$ level of probability where the F-value was significant. 


\section{RESULTS}

\section{A. AM Colonization and Nutrient Content}

$G$. aggregatum and $G$. clarum formed AM in roots of $C$. hosei 6 months after transplantation under greenhouse condition (Figure 1). There was no difference in percentage of colonization between $G$. aggregatum and G. clarum. No colonization was observed in uninoculated seedlings.

Ploiarium alternifolium roots were colonized by both AM fungal species, G. aggregatum and G. clarum, 6 months after transplantation under greenhouse condition (Figure 1). There was no difference in percentage of colonization between $G$. aggregatum and $G$. clarum. Control seedlings of $P$. alternifolium were colonized by indigenous AM fungi.

Nutrient content $(\mathrm{P}, \mathrm{Zn}$ and $\mathrm{B}$ ) were higher in shoot of $C$. hosei inoculated with $G$. aggregatum and $G$. clarum than control seedlings (Figure 1 ). There was no difference in shoot nutrient content between both AM fungi. AM colonization by $G$. aggregatum and $G$. clarum increased shoot $P$. content of $P$. alternifolium. There was no difference in shoot nutrient content between $G$. aggregatum and $G$. clarum.

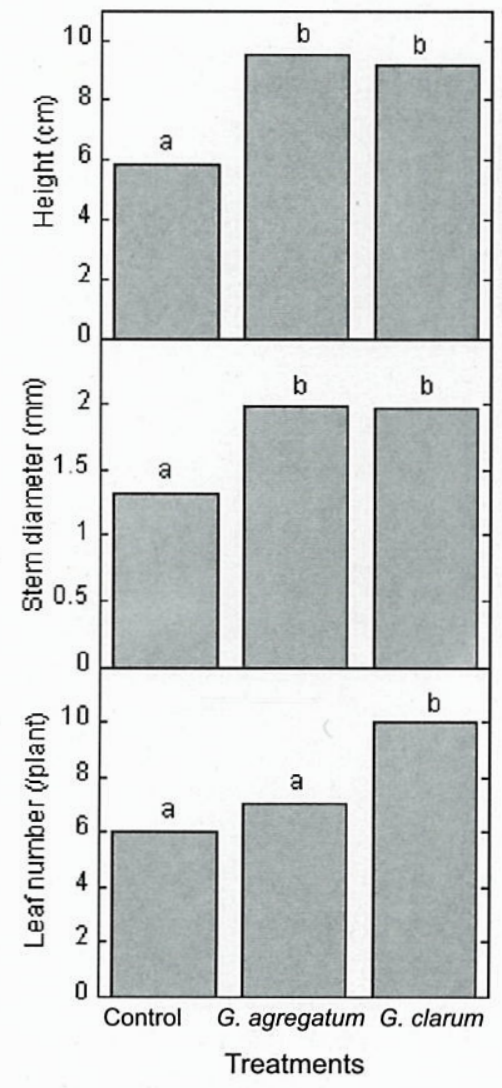

Figure 1. Plant height, diameter and leaf number of $C$. hosei inoculated with or without AM fungi, $G$. aggregatum and $G$. clarum under greenhouse condition 


\section{B. Plant Growth and Survival Rates}

AM colonization of $G$. aggregatum increased plant height and stem diameter of $C$. hosei (Fig. 1). G. aggregatum did not increase leaf number. G. clarum also increased plant height, stem diameter and leaf number of $C$. hosei. Furthermore, inoculation $G$. aggregatum and $G$. clarum increased shoot dry weight and root dry weight of $C$. hosei (Figure 1). There was no difference in shoot dry weight and root dry weight of $C$. hosei between $G$. aggregatum and G. clarum.

AM colonization of $G$. aggregatum and $G$. clarum increased plant height, stem diameter and leaf number of $P$. alternifolium 6 months after transplantation (Figure 2). Furthermore, inoculation of $G$. aggregatum and $G$. clarum increased shoot dry weight and root dry weight (Figure 1). There was no difference in shoot height, stem diameter, leaf number, shoot and root dry weight of $P$. alternifolium between $G$. aggregatum and $G$. clarum.

AM colonization of $G$. aggregatum and $G$. clarum increased survival rates of $C$. bosei 6 months after transplantation under greenhouse conditions (Figure 3). Survival rates of P. alternifolium inoculated by both AM species were also higher than control seedlings. There was no difference in survival rates between $G$. aggregatum and $G$. clarum.

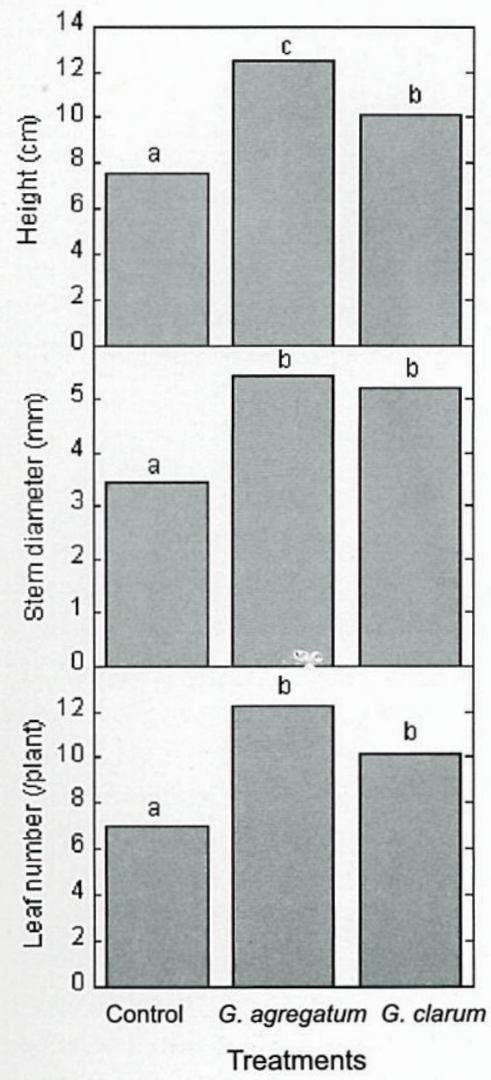

Figure 2. Plant height, diameter and leaf number of $P$. alternifolium inoculated with or without AM fungi, $G$. aggregatum and $G$. clarum under greenhouse condition 


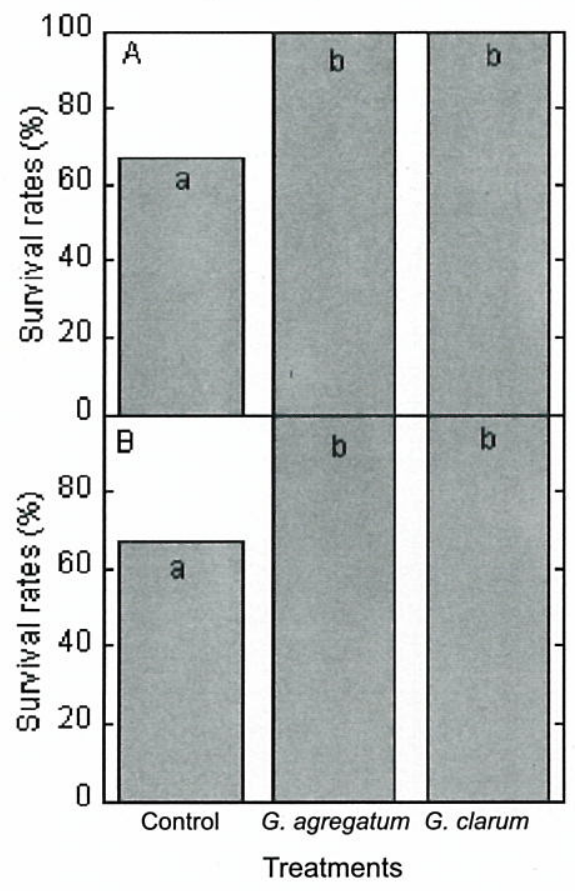

Figure 3. Survival rate of P. alternifolium (A) and C. hosei (B) inoculated with or without AM fungi, $G$. aggregatum and $G$. clarum under greenhouse condition

\section{DISCUSSION}

G. aggregatum and $G$. clarum formed AM colonization in roots of $C$. bosei and $P$. alternifolium after 6 months transplantation under greenhouse condition (Figure 1). There were few reports of presence AM colonization in roots of plant species belonging to familiy of Guttiferae. Burslem et al. (1995) observed native AM colonization of Calophyllum tetrapterum at 27 weeks after transplantation in lowland tropical rain forest of Singapore. Tawaraya et al. (2003) have reported that the native AM colonization of C. sclerophyllum and C. soulattri in tropical peat-swamp forest, Central Kalimantan, Indonesia. There was no report of presence AM colonization in roots of P. alternifolium. To the best of our knowledge, this is the first observation of AM colonization in C. hosei and P. alternifolium.

Percentage of AM colonization on individual seedlings ranged from 18 to $19 \%$ for $C$. hosei and from 27 to $32 \%$ for P. alternifolium. (Figure 1). The level of AM colonization observed on the root of $C$. hosei and $P$. alternifolium was comparable with other reports in the literature. Tawaraya et al. (2003) observed the natural AM colonization of C. sclerophyllum and C. soulattri growing in peat-swamp forest as between 18 and $60 \%$, respectively. Natural AM colonizations were observed on control $C$. hosei and $P$. alternifolium seedlings, but natural AM control seedlings (3\%) were lower than G. aggregatum and $G$. clarum. Béreau et al. (2000) also 
observed similar result that AM colonization of Dicorynia guianensis seedlings was very low in control seedlings (less than 10\%). Natural AM colonization in control seedlings was highly likely originated from the soil underneath the pots since pots were placed directly above the soil surface without any border. Direct contact between the roots and the nursery floor was the possible reason of the natural mycorrhization. It was possible that wind, water and/or insects carried the AM fungi inoculum. It was likely that inoculation of both AM fungi prevented the roots from colonization by other type of fungi including the native one.

AM colonization of both seedling species by $G$. aggregatum and $G$. clarum improved shoot $\mathrm{P}, \mathrm{Zn}$ and $\mathrm{B}$ content compared to control seedlings (Figure 1). Nutrient content was higher in shoots of inoculated (or AM fungi) seedlings than in those of controls, indicating that AM colonization improved both $C$. hosei and $P$. alternifolium nutrient uptake. This was considered as an indication of nutrient translocation in the mycelia of this fungus. Furthermore, no different between AM fungal species in this respect may indicate no different in the ability of both AM symbionts to supply $\mathrm{P}, \mathrm{Zn}$ and $\mathrm{B}$ to the host plant, or to immobilize them within the mycelium. When these are short supply their uptake may be stimulated, and when they are present in excess their uptake may be inhibited. On soils without background contamination, improved $\mathrm{Zn}$ nutrition attributable to AM has been well documented in early studies (Kothari et al., 1991). It is well known that the enhanced nutritional status of a plant manifests in its improved growth (Jeffries and Barea, 2001). In contrast, as mycorrhizas may be useful in nutrient or heavy metal uptake without connected enhancement of growth and $\mathrm{P}$ uptake Joner and Leyval, 2001). Chen et al. (2003) reported that AM hyphal contribution to $\mathrm{Zn}$ uptake by the host plant reached its maximum value at the $Z \mathrm{n}$ addition level of $50 \mathrm{mg} \mathrm{kg}-1$, in which $\mathrm{Zn}$ uptake via the extramatrical hyphae comprised $22 \%$ of total uptake. It is important hypothesis because $\mathrm{Zn}$ is an essential nutrient for plant growth and at the same time a potentially toxic metal when excessive amount are present.

Shoot $\mathrm{P}$ content were higher in shoots of inoculated seedlings than in those of control seedlings (Figure 1). AM fungi increased shoot $\mathrm{P}$ content of Macaranga denticulate (Euphorbiaceae) at 120 days after transplantation in Thailand (Youpensuk et al., 2004). Shoot P content of Tectona grandis (Verbenaceae) at 60 days after transplantation from India were higher in AM seedlings (Rajan et al., 2000). AM Glomus sp. and Acaulospora laevis increased $\mathrm{P}$ content of Acacia concurrences (Leguminosae) at 69 days after transplantation in Western Australia (Jasper et al.,1989). AM colonization increased shoot P content of Acacia nilotica and Leucaena leucocephala (Leguminosae) at 12 weeks after transplantation under greenhouse condition (Michelsen and Rosendahl, 1990). Reena and Bagyaraj (1990) confirmed that AM colonization increased $\mathrm{P}$ uptake of $A$. nilotica and Calliandra calothyrsus seedlings (Leguminosae) at 180 days after transplantation under greenhouse condtion. G. aggregatum and $G$. clarum increased P contents of $P$. alternifolium seedlings by up to $164-171 \%$. In addition, both AM colonization increased $\mathrm{P}$ uptake of $C$. hosei by up to $39-67 \%$. These increases were comparable to the $57 \%$ and $132 \%$ increases that were observed in $T$. grandis (Verbenaceae) inoculated with AM fungi (Rajan et al.,2000).

AM fungi may improve the balance of mineral nutrition in shoot of both species, especially for trace element B (Table 1). Boron (B) is an essential micronutrient for plants but it is thought not to be essential for mycorrhizal fungi (Lehto et al., 2004). The most rapid response to $\mathrm{B}$ deficiency is the inhibition of root elongation and reproductive growth of flowering plants (Dell and Huang, 1997). The early inhibition of root growth of seedlings, 
compared to shoot growth, increases the shoot root ratio. Sakya et al. (2002) reported that B deficiency symptoms of Eucalyptus globulus seedlings appeared at day 5 in the nutrient solution containing less than $0.27 \mathrm{M} \mathrm{B}$. Moreover, the internal critical B concentration were estimated for shoot growth between 12-16 mg B kg-1 dry weight in E. globulus trees up to three years of age in Southeast Asia.

Both AM fungi also increased shoot dry weight (133-152\%) and root dry weight (100$186 \%$ ) of C. hosei (Figure 1). AM colonization of G. aggregatum and G. clarum increased shoot dry weight (106-128\%) and root dry weight (170-203\%) of P. alternifolium. Plant height, stem diameter and leaf number of AM seedlings were higher than control seedlings (Figure1 and Figure 2). Thirteen AM species increased plant height, stem diameter and leaf number of $C$. calothyrsus (Leguminosae) at 180 days after transplantation (Reena and Bagyaraj, 1990). Nine AM species increased also plant height, stem diameter and dry weight of $T$. grandis (Verbenaceae) at 180 days after transplantation. G. clarum colonization increased total dry weight of Araucaria angustifolia (Araucariaceae) at 21 months after transplantation from Brazil (Zandavalli et al., 2004). AM colonization increased total dry weight of Australian rain forest tree Flindersia brayleana (Rutaceae) and Acmena resa (Myrtaceae) seedlings at 6 months after transplantation under greenhouse condition (Gehring, 2003). Total dry weight of Dicorynia guianensis (Caesalpiniaceae) from French Guiana at 350 days under medium light intensity was higher in AM seedlings than control seedlings (Béreau et al., 2000).

In field scale, survival rate is very important because seedlings stock becomes very valuable for rehabilitating degraded forest. Survival rate of both were $100 \%$ after 6 months inoculations (Figure 3). These results were higher than survival rates of two tropical trees species from Panama inoculated by AM fungi, Ochroma pyramidale $(97 \%)$ and Luehe seemanii $(52 \%)$ (Kiers et al., 2000). Generally, 120\% seedlings stock should be prepared prior to any reforestation activity, however this study suggested that much more seedlings are needed when seedlings are not inoculated with AM fungi since field condition is much more extreme than that of nursery. On the contrary, using inoculated seedlings might prevent from unnecessary large amount of seedlings stock. These results might be significant when reforesting vast amount of areas, as it would reduce significant cost of seedlings preparation in peat-swamp area.

In this experiment, we succeeded to make rooting in two peat-swamp tree seedlings, $P$. alternifolium and $C$. hosei, with propagation cutting system under greenhouse use fogging system developed by Sakai et al. (2002). This technique has been used for producing seedlings of Shorea leprosula, S. selanica and S. platyclados (Dipterocarpaceae). For accelerating reforestation program, Nair and Seeni (2003) proposed that Calophyllum seedlings can be multiplied by tissue culture technology, but Calophyllum roots were growth slowly. It is promising that young rooted seedlings can acclimatized with helping AM fungi inoculation to stimulate root development and accelerate early growth of seedlings, especially for slow growing tree species origin from peat swamp forest. It is important to consider: (1) to decide and develop silviculture of mass production peat-swamp trees species technology, especially rooting seedlings development; (2) to select AM fungi for stimulating early growth seedling with different indigenous trees species under nursery condition. 


\section{CONCLUSION AND SUGGESTION}

In conclusion, colonization of $G$. aggregatum and G. clarum increased plant growth, nutrient uptake and survival rates of and $C$. hosei and $P$. alternifolium seedlings 6 months after transplantation under greenhouse condition. There was no different effect between AM inoculation on plant growth with the AM fungi species used. On the other hand, G. aggregatum is exotic species although it can perform well with both species. When native species is unavailable than exotic AM fungi should be selected providing inoculated seedlings are improved. G. clarum might be used and selected if both species are selected for rehabilitating activity. Furthermore, study on the field condition is required to confirm and investigate this preliminary finding. The results suggested that AM inoculation technology can accelerate establishment of the planting stock in a large nursery scale for rehabilitating tropical peatswamp forest.

\section{REFERENCES}

Augé, R.M., J.L. Moore, K. Cho, J.C. Stutz, D.M. Sylvia, A. Al-Agely and A.M. Saxton. 2003. Relating foliar dehydration tolerance of mycorrhizal Phaseolus vulgaris to soil and root colonization by hyphae. J. Plant Physiol. 160:1147-1156.

Azcón-Aguilar, C. and J.M. Barea. 1996. Arbuscular mycorrbizas and biological control of soilborne plant pathogens an overview of the mechanisms involved. Mycorrhiza 6 : 457464.

Béreau, M., T.S. Barigah, E. Louisanna and J. Garbaye. 2000. Effects of endomycorrhizal development and light regimes on the growth of Dicorynia guianensis Ammshoff seedlings. Ann. For. Sci. 57: 725-733.

Brundrett, M., N. Bougher, B. Dell, T. Grove and N. Malajczuk. 1996. Working with mycorrhizas in Forestry and Agriculture. ACIAR Monograph 32, Canberra.

Burslem, D.F.R.P, P.J. Grubb and Turner, I.M. 1995. Response to nutrient addition among shade-tolerant tree seedlings of lowland tropical forest in Singapore. The J. Ecol. 83 : 113-122.

Chen, B.D., X.L. Li, H.Q.Tao, P. Christie and M.H.Wong. 2003. The role of arbuscular mycorrhizal in zinc uptake by red clover growing in a calcareous soil spiked with various quantities of zinc. Chemosphere 50:839-846.

CITES, 2005. Convention on International Trade in Endangered Species of Wild Fauna and Flora. Appendices I, II and III of CITES. UNEP. 48 pp.

Dell, B. and L. Huang. 1997. Physiological response of plants to low boron. Plant and Soil 193:103-120.

Gehring, C.A. 2003. Growth response to Arbuscular mycorrhizae by rain forest seedlings vary with light intensity and tree species. Plant Ecol. 167:127-139. 
George, E. 2000. Nutrient uptake : Contribution of arbuscular mycorrhizal fungi to plant mineral nutrition. In: Y.Kapulnik and D.D. Douds, Jr. (Eds.), Arbuscular mycorrhizas: Physiology and Function, Kluwer Academic Publishers, Dordrecht, the Netherlands 307-343 pp.

Guadarrama, P., J. Álvarez-Sánchez and O. Briones. 2004. Seedling growth of two pioneer tropical tree species in Competition: The role of arbuscular mycorrhizae. Euphytica 138 :113-121.

Jasper, D.A., L.K. Abbott and A.D. Robson. 1989. Acacias respond to additions of phosphorus and to inoculation with VA mycorrhizal fungi in soils stockpiled during mineral sand mining. Plant Soil 115:99-108.

Jeffries P., S. Gianinazzi, S. Perotto, K. Turnau and J.M. Barea. 2003. The contribution of arbuscular mycorrhizal fungi in sustainable maintenance of plant health and soil fertility. Biol. Fertil. Soils. 37: 1-6.

Jeffries, P. and J.M. Barea. 2001. Arbuscular Mycorrhiza- a Key Component of Sustainable Plant-Soil Ecosystems. The Mycota IX Fungal Association Hock (Ed.) 95-113, Springer-Verlag Berlin Heidelberg.

Joner, E.J. and C. Leyval. 2001. Time-course of heavy metal uptake in maize and clover as affected by root density and different mycorrhizal inoculation regimes. Biol. Fertil. Soils.33:351-357.

Khan, M.R., M. Kihara and A.D. Omoloso. 2002. Antimicrobial activity of Calophyllum soulatri. Fitoterapia $73: 741-743$.

Kiers, E.T., C.E. Lovelock, E.L. Krueger and E.A. Herre. 2000. Differential effects of tropical arbuscular mycorrhizal funga inocula on root colonization and tree seedling growth: implications for tropical forest diversity. Ecol. letters 3:106-113.

Kobuski, C.E. 1950. Studies in the Theaceae, XIX, the genera Archytaea and Ploiarium. Journal of The Arnold Arboretum Vol. XXXI : 196-207.

Kothari, S.K., H. Marschener and V. Romheld. 1991. Contribution of the VA mycorrhizal hyphae in acquisition of phosphorus and zinc by maize grown in a calcareous soil. Plant Soil $131: 177-185$.

Lee, S.S. 1990. The mycorrhizal association of the Dipterocarpaceae in the tropical rain forests of Malaysia. Ambio 19:383-385.

Lehto, T., A. Lavola, E. Kallio and P.J. Aphalo. 2004. Boron uptake by ectomycorrhizas of silver birch. Mycorrhiza 14:209-212.

Leong, Y-W. and L.J. Harrison. 1999. (20R,23E)-Eupha-8,23-diene-3b,25-diol from Tripetalum cymosum. Phytochemistry 50: 849-857.

Marschner H. and B. Dell. 1994. Nutrient uptake in mycorrhizal symbiosis. Plant Soil 159: 89102. 
McGonigle, T.P., M.H. Miller, D.G. Evans, G.L. Fairchild and J.A. Swan. 1990. A new method which gives an objective measure of colonization of roots by vesiculararbuscular mycorrhizal fungi. New Phytol. 115:495-501.

Michelsen, A. and S. Rosendhal. 1990. The effect of VA mycorrhizal fungi, phosphorus and drought stress on the growth of Acacia nilotica and Leucaena leucocephala seedlings. Plant Soil 124:7-13.

Miller, R.M. and J.D. Jastrow. 2000. Mycorrhizal fungi in soil structure. In: Y.Kapulnik and D.D. Douds, Jr. (Eds.), Arbuscular mycorrhizas: Physiology and Function, Kluwer Academic Publishers, Dordrecht, the Netherlands 3-18 pp.

Nair, L.G. and S. Seeni. 2003. In vitro multiplication of Calophyllum apetalum (Clusiaceae), an endemic medicinal tree of the Western Ghats. Plant Cell, Tissue and Organ Culture 75: 169-174.

Page, S.E., J.O. Rieley, Ø.W. Shotyk and D. Weiss. 1999. Interdependence of peat and vegetation in a tropical peat swamp. Phil. Trans. R. Soc. London 354 : 1885-1897.

Rajan, S.K., B.J.D. Reddy and D.J. Bagyaraj. 2000. Screening of arbuscular mycorrhizal fungi for their symbiotic efficiency with Tectona grandis. For. Ecol. Manage. 126: 91-95.

Reena, J. and D.J. Bagyaraj. 1990. Response of Acacia nilotica and Calliandra calotbyrsus to different VA Mycorrhizal Fungi. Arid Soil Research and Rehabilitation 4:261-268.

Reyes-Chilpa, R., M. Jimenez-Estrada and E. Estrada-Muñiz. 1997. Antifungal xanthones from Calophyllum brasiliensis hearthwood. J. Chem. Ecol. 23(7): 1901-1911.

Sakai, C., A. Subiakto, H.S. Nuroinah, N. Kamata and K. Nakamura. 2002. Mass propagation method from the cutting of three dipterocarp species. J. For. Res. 7:73-80.

Sakya, A.T., B.Dell and L. Huang. 2002. Boron requirements for Eucalyptus globulus seedlings. Plant Soil 246: 87-95.

Slik, J.W.F., A.D. Poulsen, P.S. Ashton, C.H. Cannon, Eichhorn, K. Kartawinata, H. Lanniari, H.Nagamasu, M. Nakagawa, M.G.L. van Nieuwstadt, J. Payne, Purwaningsih, A. Saridan, K. Sidiyasa, R.W. Verburg, C.O. Webb and P. Wilkie. 2003. A floristic analysis of the lowland dipterocarp forests of Borneo. J. Biogeography $30: 1517-1531$.

Smith, S.E., F.A. Smith and I. Jakobsen. 2003. Mycorrhizal fungi can dominate phosphate supply to plants irrespective of growth responses. Plant Physiology 133:16-20.

Smith, S. and .D.J. Read. 1997. Mycorrhizal symbiosis. 2nd edition. Academic Press, San Diego, California.

Soerianegara, I. and R.H.M.J. Lemmens. 1994. Timber trees : Major commercial timbers. Plant Resources of South-East Asia No. 5 (1). Prosea, Bogor, Indonesia.

Sosef, M.S.M., L.T. Hong and S. Prawirohatmodjo. 1998. Timber trees: Lesse-known timbers. Plant Resources of South-East Asia No. 5 (3). Prosea, Bogor, Indonesia. 
Tawaraya, K., Y. Takaya, M. Turjaman, S.J. Tuah, S.H. Limin, Y. Tamai, J.Y. Cha, T. Wagatsuma and M. Osaki. 2003. Arbuscular mycorrbizal colonization of tree species grown in peat swamp forests of Central Kalimantan, Indonesia. For. Ecol. Manage. 182:381-386.

Youpensuk, S., S. Lumyong, B. Dell and B. Rerkasem. 2004. Arbuscular mycorrbizal fungi in the rhizosphere of Macaranga denticulate Muell. Arg., and their effecton the host plant. Agroforestry System 60: 239-246.

Zandavalli, R.B., L.R. Dillenburg and P.V.D. de Souza. 2004. Growth responses of Araucaria angustifolia (Araucariaceae) to inoculation with the mycorrhizal fungus Glomus clarum. Applied Soil Ecology 25: 245-255. 